JOURNAL of

TOXICOLOGY and

ENVIRONMENTAL

HEALTH
Journal of Toxicology and Environmental Health, Part A Current Issues

\title{
Exposure of Children to Ultrafine Particles in Primary Schools in Portugal
}

João Cavaleiro Rufo, Joana Madureira, Inês Paciência, Klara Slezakova, Maria do Carmo Pereira, Cristiana Pereira, João Paulo Teixeira, Mariana Pinto, André Moreira \& Eduardo de Oliveira Fernandes

To cite this article: João Cavaleiro Rufo, Joana Madureira, Inês Paciência, Klara Slezakova, Maria do Carmo Pereira, Cristiana Pereira, João Paulo Teixeira, Mariana Pinto, André Moreira \& Eduardo de Oliveira Fernandes (2015) Exposure of Children to Ultrafine Particles in Primary Schools in Portugal, Journal of Toxicology and Environmental Health, Part A, 78:13-14, 904-914, DOI: $10.1080 / 15287394.2015 .1048866$

To link to this article: http://dx.doi.org/10.1080/15287394.2015.1048866

+ View supplementary material $๘$

里 Published online: 13 Jul 2015.

Submit your article to this journal ๘

山ll Article views: 116

Q View related articles $\sqsubset$

View Crossmark data \ulcorner 
Journal of Toxicology and Environmental Health, Part A, 78:904-914, 2015

Copyright $\odot$ Taylor \& Francis Group, LLC

ISSN: 1528-7394 print / 1087-2620 online

DOI: $10.1080 / 15287394.2015 .1048866$

\title{
EXPOSURE OF CHILDREN TO ULTRAFINE PARTICLES IN PRIMARY SCHOOLS IN PORTUGAL
}

\author{
João Cavaleiro Rufo ${ }^{1}{ }^{\circledR}$, Joana Madureira ${ }^{1}$, Inês Paciência ${ }^{1}$, Klara Slezakova ${ }^{2}$, \\ Maria do Carmo Pereira ${ }^{2}$, Cristiana Pereira ${ }^{3}$, João Paulo Teixeira ${ }^{3}$, Mariana Pinto ${ }^{4}$, \\ André Moreira $^{4}$, Eduardo de Oliveira Fernandes ${ }^{1}$ \\ ${ }^{1}$ Institute of Mechanical Engineering and Industrial Management, Porto, Portugal \\ ${ }^{2}$ Laboratory for Process Engineering, Environment, Biotechnology and Energy (LEPABE), \\ Faculty of Engineering of University of Porto, Porto, Portugal \\ ${ }^{3}$ National Institute of Health, Porto, Portugal \\ ${ }^{4}$ Faculty of Medicine of the University of Porto, Porto, Portugal
}

Children spend a large part of their time at schools, which might be reflected as chronic exposure. Ultrafine particles (UFP) are generally associated with a more severe toxicity compared to fine and coarse particles, due to their ability to penetrate cell membranes. In addition, children tend to be more susceptible to UFP-mediated toxicity compared to adults, due to various factors including undeveloped immune and respiratory systems and inhalation rates. Thus, the purpose of this study was to determine indoor UFP number concentrations in Portuguese primary schools. Ultrafine particles were sampled between January and March 2014 in 10 public primary schools (35 classrooms) located in Porto, Portugal. Overall, the average indoor UFP number concentrations were not significantly different from outdoor concentrations $\left(8.69 \times 10^{3} \mathrm{vs} .9 .25 \times 10^{3} \mathrm{pt} / \mathrm{cm}^{3}\right.$, respectively; considering $6.5 \mathrm{~h}$ of indoor occupancy). Classrooms with distinct characteristics showed different trends of indoor UFP concentrations. The levels of carbon dioxide were negatively correlated with indoor UFP concentrations. Occupational density was significantly and positively correlated with UFP concentrations. Although the obtained results need to be interpreted with caution since there are no guidelines for UFP levels, special attention needs to be given to source control strategies in order to reduce major particle emissions and ensure good indoor air quality.

In the last decades, the prevalence of respiratory diseases and allergy among children has been increasing in developed countries (Correia de Sousa et al., 2010). Previous studies showed evidence that this surge of respiratory diseases cannot be exclusively explained by genetic changes and is more probably associated with environmental and/or lifestyle changes (Etzel 2007; Selgrade et al., 2008). Part of these changes includes the indoor air quality (IAQ), which is determined by a combination of pollution sources, all of them having specificities associated to the place, the climate, and the culture: the local ambient air, the building characteristics, and the indoor activities (Oliveira Fernandes et al., 2008; AnnesiMaesano et al., 2013).

Apart from home, children spend a large portion of time at school, which might be reflected as chronic exposure to indoor air parameters (Zhang et al., 2006; Buonanno et al., 2012, 2013a; Mazaheri et al., 2014). Therefore, if IAQ in schools is poor, children might be at higher risk of developing respiratory diseases (Buonanno et al., 2014). In primary schools, IAQ is generically characterized by vast assortment of various exposures to certain indoor pollutants including particulate matter

Address correspondence to João Cavaleiro Rufo, Institute of Mechanical Engineering and Industrial Management, Rua Dr. Roberto Frias, 4200-465 Porto, Portugal. E-mail: jcrufo@gmail.com 
(PM) (Englert 2004; Madureira et al., 2009; 2012; Annesi-Maesano et al., 2013).

Ultrafine particles (UFP) are small particles with an aerodynamic diameter less than $0.1 \mu \mathrm{m}$ and generally associated with higher particle number concentrations, surface area, and higher toxicity compared to larger particles $\left(\mathrm{PM}_{2.5}\right.$ and $\left.\mathrm{PM}_{10}\right)$ (Sioutas et al., 2005). Moreover, UFP have been associated with more severe toxicity when compared to fine and coarse particles due to their ability to penetrate cell membranes (Peters et al., 1997; Penttinen et al., 2001; Semmler et al., 2004; Carosino et al., 2015). Results from previous studies suggested that prolonged exposure to high number concentrations of UFP may be responsible for an impairment of lung function and/or development and exacerbation of respiratory diseases such as asthma or chronic obstructive pulmonary disease (COPD) (Terzano et al., 2010; Stanek et al., 2011; Slezakova et al., 2012; Ferreira et al., 2013; Carosino et al., 2015). In addition, children tend to be more susceptible to UFP toxicity when compared to adults, particularly due to their undeveloped immune and respiratory systems (Schwartz 2004; Foos et al., 2008).

Ultrafine particles may originate outdoors, from vehicle emissions and gas-to-particle conversions (Levy et al., 2003; Vigotti et al., 2007). However, indoor UFP originate from a wide range of indoor sources and occupant-related activities such as cooking, smoking, cleaning, and painting (Wallace et al., 2002; Vinzents et al., 2005; Weichenthal et al., 2007). One of the potential approaches to control indoor air pollutant concentrations is to reduce emission sources (Oliveira Fernandes et al., 2008). Therefore, in order to decrease the number concentrations of UFP in primary schools, the major sources of UFP need to be identified.

The aim of this investigation was to determine UFP number concentrations in Portuguese primary schools. The specific objectives were to (i) measure UFP number concentrations in 10 Portuguese primary schools in comparison with data obtained in other studies; (ii) characterize the trends of UFP number concentrations in classrooms with distinct characteristics; and (iii) assess the influence of natural ventilation on indoor number concentrations of UFP.

\section{MATERIALS AND METHODS}

\section{Sampling Sites, Walkthrough Inspection, and Checklist}

Between January and March 2014, UFP were sampled in 10 public primary schools. All schools (S1 to S10) were in Porto, which is the second largest city in Portugal, located in the north of the country $\left(41.16^{\circ} \mathrm{N}, 8.62^{\circ} \mathrm{W}\right)$. Depending on the number of classrooms available, 2-4 classrooms in each school inhabited by 8 - to 10 -year-old children were investigated using the same sampling protocol. In total, 35 classrooms were sampled. The sample collections were performed during regular daily activities and under representative conditions of occupancy and use of classrooms. In order to evaluate the influence of outdoor sources to indoors, UFP number concentrations were also measured in ambient air (outdoors). Information regarding the building and indoor spaces was obtained in a walkthrough inspection using a detailed checklist (Tables 1S and $2 \mathrm{~S}$ ). The checklist recorded information with respect to building construction, age and size, number of floors, number of occupants, ventilation and heating systems, past occurrences or visible problems, building usage, and potential indoor sources, as well as outdoor environment. Classroom characteristics, such as area, floor, walls, and ceiling conditions, windows, scholar activity products (paintings, glues, etc.), maintenance routines, and cleaning procedures, were also registered, as well as materials including classroom furniture, presence of chalkboards, copiers, plants, and information regarding use of environmental modifiers including air fresheners and insecticides.

\section{Indoor and Outdoor Air Sampling}

Indoor measurements were conducted during three days of a school week, avoiding Mondays and Fridays (one week per school). 
Each day UFP were collected in 1 classroom for a period of $8.5 \mathrm{~h}$ (between 9:00 to 17:30), which corresponded to the periods when children were present at school. There were 3 recess periods: from 10:30 to 11:00, from 12:30 to 14:00, and from 16:00 to 16:30.

Two portable condensation particle counters (P-Trak model 8525, TSI, Inc., Shoreview, $M N$ ) were used for measurement of UFP number concentrations. The operation mechanism of these particle counters is based on the principle of condensing $100 \%$ grade isopropyl alcohol (Sigma-Aldrich, Steinheim, Germany) onto UFP in order to increase their dimensions to detectable sizes (Fonseca et al., 2014). The particle detection limit ranged from 0.02 to larger than $1 \mu \mathrm{m}$. Instruments were installed inside each classroom and set to continuously measure during at least one school day (8.5 h, avoiding Mondays and Fridays). Logging intervals were set to $1 \mathrm{~min}$ between samples, in agreement with previous published investigations (Diapouli et al., 2007). Further detailed characterization of the equipment was previously reported (Diapouli et al., 2007).

Safe and childproof sampling locations were selected according to the International Standardization Organization (ISO, 2004). The instruments that were sampling indoors were mounted on a flat surface with a height of 1.2 to $1.5 \mathrm{~m}$ in order to simulate the primary school children's breathing zone. In addition, in each classroom, particle counters were placed as far as possible from windows or doors, as well as from potential sources of UFP such as heaters, blackboards, and printers. The sampling process was supervised by a researcher who recorded information regarding classroom occupancy, ventilation, and occupant behavior and activities.

Outdoor UFP were also sampled for a period of $8.5 \mathrm{~h}$ (from 9:00 to 17:30) during one day of the same school week as indoor measurements (avoiding Mondays and Fridays). Outdoor samples of UFP were collected in the school's playground, at a safe distance from intense activity zones, such as football fields, and collections were always positioned in open areas avoiding obstacles that might interfere with data acquisition, such as trees and walls. Similar to the indoor setup, the instrument was positioned on portable supports (1.2 to $1.5 \mathrm{~m}$ above ground). In situations of rain, an impermeable cover was mounted on each instrument, carefully leaving the sampling inlet uncovered such that sampling was not compromised.

Carbon dioxide $\left(\mathrm{CO}_{2}\right)$, temperature $(\mathrm{T})$, and relative humidity $(\mathrm{RH})$ were recorded concurrently with both indoors and outdoors UFP measurements during the sampling campaign. These parameters were measured by an IAQ-CALC monitor (model 7545, TSI Inc., Shoreview, MN) with logging intervals of $5 \mathrm{~min}$. In each sampling location (2 to 4 indoors and 1 outdoors) the instruments were placed approximately 15 to $20 \mathrm{~cm}$ apart from particle counters in order to avoid measurements disrupting due to instrument's operation. Calibration was performed once per year according to manufacturer specifications.

\section{Statistical Analysis}

Statistical analysis was performed using SPSS Statistics v20 (IBM). The one-sample Kolmogorov-Smirnov test was used to verify data normality. The hypothesis of UFP number concentrations being normally distributed was excluded, and thus nonparametric tests were used to further analyze data. Spearman's correlation coefficient (rho) and linear regression analysis were used to determine how indoor UFP number concentrations correlated with indoor $\mathrm{CO}_{2}$ levels. Statistical significance was considered when $p<.05$. For the indoor air parameters, the recess periods were not considered in the analysis.

\section{RESULTS}

A summary of the mean values of indoor and outdoor UFP number concentrations measured in each school, as well as the indoor/outdoor $(\mathrm{I} / \mathrm{O})$ ratios, is displayed in Table 1. These values were estimated using all 
TABLE 1. Mean UFP Concentrations and Indoor/Outdoor Ratios (I/O) in the 10 Primary Schools

\begin{tabular}{|c|c|c|c|c|c|c|c|c|c|c|}
\hline \multirow[b]{3}{*}{ School ID } & \multirow{3}{*}{$\begin{array}{l}\text { Number of } \\
\text { classrooms }\end{array}$} & \multicolumn{8}{|c|}{ UFP number concentrations $\left(\times 10^{3} \mathrm{pt} / \mathrm{cm}^{3}\right)$} & \multirow{3}{*}{$\begin{array}{l}\mathrm{I} / \mathrm{O} \\
\text { ratio }\end{array}$} \\
\hline & & \multicolumn{4}{|c|}{$\begin{array}{l}\text { Indoor ( } 6.5 \mathrm{~h} \text { averaging period, occupational } \\
\text { time) }\end{array}$} & \multicolumn{4}{|c|}{ Outdoor (8.5 $\mathrm{h}$ averaging period) } & \\
\hline & & Mean & Median & Minimum & Maximum & Mean & Median & Minimum & Maximum & \\
\hline S1 & 2 & 3.8 & 3.8 & 1.7 & 5.9 & 2.2 & 1.8 & 0.6 & 6.5 & 1.76 \\
\hline S2 & 4 & 6.6 & 7.1 & 5.0 & 7.4 & 7.3 & 7.2 & 3.8 & 20.4 & 0.90 \\
\hline S3 & 4 & 5.9 & 5.8 & 3.5 & 8.4 & 19.6 & 15.4 & 3.6 & 143.0 & 0.30 \\
\hline S4 & 4 & 8.0 & 6.9 & 6.2 & 11.9 & 3.2 & 2.6 & 1.2 & 8.7 & 2.49 \\
\hline S5 & 4 & 16.0 & 16.0 & 6.4 & 25.6 & 8.8 & 7.3 & 3.3 & 43.9 & 1.81 \\
\hline S6 & 4 & 12.7 & 12.7 & 7.4 & 18.1 & 10.0 & 9.2 & 3.8 & 23.7 & 1.27 \\
\hline S7 & 4 & 8.8 & 8.2 & 7.6 & 11.3 & 10.7 & 10.6 & 3.3 & 35.0 & 0.82 \\
\hline S8 & 2 & 7.6 & 7.6 & 7.5 & 7.7 & 11.2 & 9.5 & 3.0 & 65.3 & 0.68 \\
\hline S9 & 2 & 8.4 & 8.4 & 8.0 & 8.8 & 10.1 & 9.7 & 5.8 & 24.9 & 0.83 \\
\hline S10 & 4 & 9.0 & 8.1 & 7.6 & 12.4 & 9.4 & 8.8 & 2.1 & 34.3 & 0.96 \\
\hline Total & 34 & 8.7 & 7.9 & 1.7 & 25.6 & 9.3 & 9.0 & 0.6 & 143.0 & - \\
\hline
\end{tabular}

Note. The mean values presented are obtained from the mean UFP concentrations measured in the respective school's classroom. UFP, ultrafine particles; I/O, indoor/outdoor ratios.

measurements from all sampled microenvironments. Further, outdoor levels corresponded to 8.5-h sampling, whereas indoor values were estimated using 6.5-h measurements (recess periods were not included) in $2-4$ indoor locations. The UFP sampling was not possible in one of the classrooms in S9; thus, only 34 of the 35 classrooms provided information regarding UFP concentrations. Overall, indoor UFP number concentrations $\left(8.69 \times 10^{3} \mathrm{pt} / \mathrm{cm}^{3}\right)$ were not significantly different from outdoor concentrations $\left(9.25 \times 10^{3} \mathrm{pt} / \mathrm{m}^{3}\right)$. Six of 10 schools, namely, S2, S3, S7, S8, S9, and S10 exhibited higher outdoor UFP concentrations than indoor ones, with S3 displaying the lowest I/O ratio (0.3). However, three of the four remaining schools (S1, S4, and S5) showed high indoor UFP concentrations compared to respective outdoor levels $(\mathrm{I} / \mathrm{O}>1.7)$. The most extreme case was $\mathrm{S} 4$, which presented indoor UFP number concentrations 2.5-fold higher than outdoors.

In order to investigate the trends of indoor UFP, the obtained levels were compared among groups of classrooms sharing similar building and furnishing characteristics (see Tables 1S and $2 \mathrm{~S}$ for more detailed information on school building characteristics). The results summarized in Table 2 showed a significant tendency for rising UFP levels in classrooms with furniture built out of wood. In addition, classrooms with laminated blinds (every classroom in S6 to S10) displayed a significant tendency for higher UFP than classrooms with textile curtains. Classrooms with chalkboards (one in S3, S9, and S10; two in S4 to S7) did not exhibit a marked tendency for higher UFP number concentrations. Regression analysis showed a significant positive correlation between area of the classrooms $\left(\mathrm{m}^{2}\right)$ and concentrations of UFP (data not shown). Consequently, the relationship between occupational density ( $\mathrm{m}^{2}$ /occupant) and UFP concentrations was also significant (Figure S1).

To investigate the indoor/outdoor UFP exchanges due to the opening and closing of windows in primary schools, the collected data regarding $\mathrm{CO}_{2}$ (considered as a marker of ventilation; (Daisey et al., 2003; ASHRAE 2004; Mahyuddin et al., 2008) concentrations in each classroom were analyzed (Table 3S). Data demonstrated that $\mathrm{CO}_{2}$ levels in classrooms were significantly negatively correlated with indoor UFP number concentrations. Further, a regression analysis was performed to further investigate this result. The model of linear regression between $\mathrm{CO}_{2}$ and indoor UFP 
TABLE 2. Trends of Indoor Ultrafine Particle Concentration in Relation to Different Classroom Characteristics

\begin{tabular}{|c|c|c|c|c|}
\hline Classroom characteristics & & $\begin{array}{l}\text { Number of } \\
\text { classrooms }\end{array}$ & $\begin{array}{l}\text { Mean UFP } \\
\left(\times 10^{3} \mathrm{pt} / \mathrm{cm}^{3}\right)\end{array}$ & $p$ \\
\hline \multirow[t]{3}{*}{ Classroom location } & Ground floor & 15 & 10.7 & .073 \\
\hline & First floor & 16 & 7.6 & \\
\hline & Second floor & 4 & 9.0 & \\
\hline \multirow[t]{2}{*}{ Board type } & White board & 24 & 8.2 & .127 \\
\hline & Chalk board & 11 & 10.8 & \\
\hline \multirow[t]{2}{*}{ Classroom equipped with a sink } & No & 19 & 8.8 & .306 \\
\hline & Yes & 16 & 9.3 & \\
\hline \multirow[t]{2}{*}{ Wood furniture } & No & 4 & 4.9 & .006 \\
\hline & Yes & 31 & 9.6 & \\
\hline \multirow[t]{2}{*}{ Floor covering material } & Synthetic & 22 & 8.9 & .425 \\
\hline & Wood & 13 & 9.4 & \\
\hline \multirow[t]{2}{*}{ Suspended ceiling } & No & 26 & 8.5 & .839 \\
\hline & Yes & 9 & 10.7 & \\
\hline \multirow[t]{2}{*}{ Type of window glazing } & Single & 20 & 7.5 & .107 \\
\hline & Double & 15 & 11.0 & \\
\hline \multirow{2}{*}{ Curtains standard material } & Textile & 18 & 8.5 & .010 \\
\hline & Laminated & 17 & 9.6 & \\
\hline \multirow[t]{2}{*}{ Heaters located bellow windows } & No & 11 & 8.4 & .734 \\
\hline & Yes & 24 & 9.3 & \\
\hline \multirow[t]{2}{*}{ Visible mold growth } & No & 29 & 9.0 & .789 \\
\hline & Yes & 6 & 9.5 & \\
\hline
\end{tabular}

Note. The numbers in bold represent statistical significant differences $(p<0.05)$.

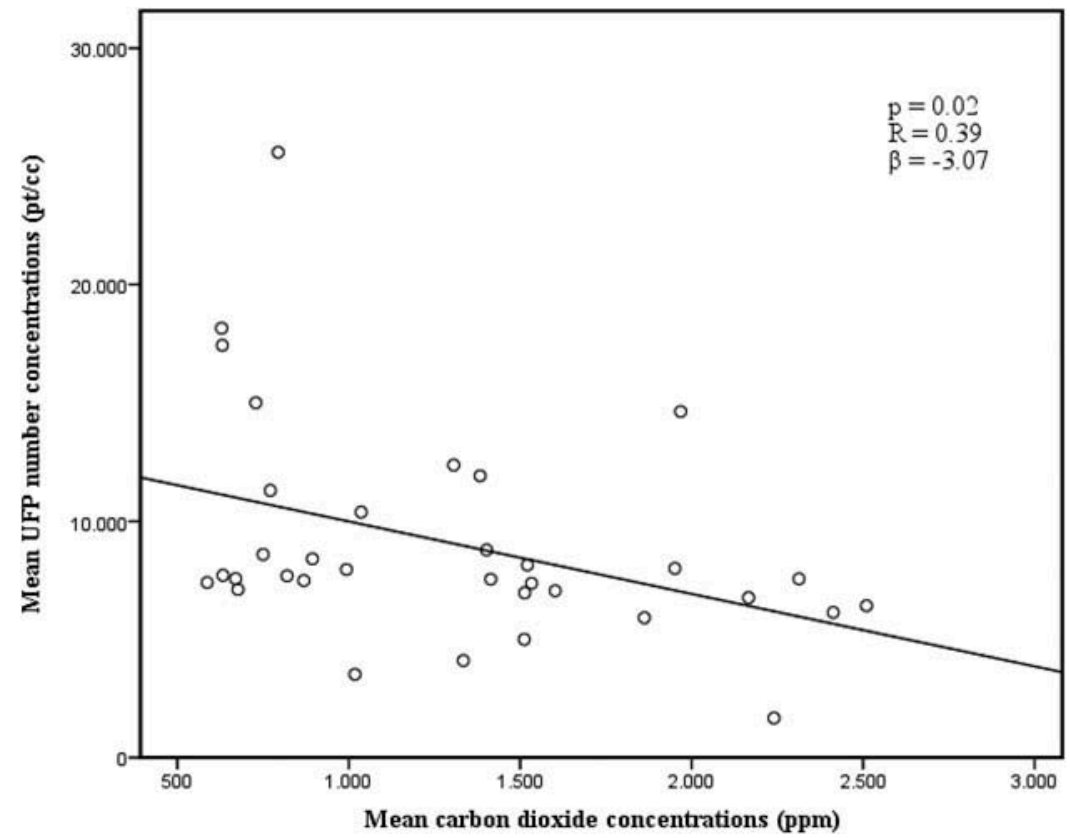

FIGURE 1. Linear regression analysis investigating the association between indoor carbon dioxide and indoor ultrafine particle (UFP) number concentrations ( $n=34$ classrooms).

concentrations was significant, and the estimation curve showed that as $\mathrm{CO}_{2}$ concentrations decreased, the indoor number concentrations of UFP tended to rise (Figure 1).

\section{DISCUSSION}

The differences between UFP levels in the 10 schools may be associated with building characteristics and indoor activities (Morawska 
et al., 2013). School 5 (S5) was the only school that cooked meals for children, which may be the source of such high levels of indoor UFP due to combustion activity associated with cooking (Zhang et al., 2012; Ferreira et al., 2013). The type of the outdoor environment may also exert influence on the potential UFP levels. Morawska et al. (2008) compared UFP number concentrations across a wide range of environments (71 studies ranging from clean places to tunnels). Specifically for urban sites, estimated means between $7.2 \times 10^{3}$ and 10.7 $\times 10^{3} \mathrm{pt} / \mathrm{cm}^{3}$ (based on 24 studies) were found, similar to our present study.

Since there are no guideline values for UFP, in order to better understand the extent of UFP concentrations on indoor air of 10 schools, the results were compared with previously published studies (Table 3). Only one Portuguese study was found (Fonseca et al., 2014) that sampled UFP number concentrations, in three preschools. Despite the different type of education institution (preschools vs. primary schools) the obtained levels of UFP were in general similar to those of the current investigation $\left(7.14 \times 10^{3}\right.$ to $\left.1.13 \times 10^{4} \mathrm{pt} / \mathrm{cm}^{3}\right)$. Other information on UFP in schools is derived predominantly from Europe and North America. Fromme et al. (2007), who analyzed 36 classrooms in Germany, showed that levels of UFP were 1.3-fold lower than concentrations in this study (mean of $6.5 \times 10^{3} \mathrm{pt} / \mathrm{cm}^{3}$ ). In comparison with a study conducted in 37 classrooms in Canada (Weichenthal et al., 2008), UFP in Portuguese schools were approximately 1.6- to 1.9-fold higher. In contrast, studies on UFP in 39 primary schools in Spain (Reche et al., 2014; Rivas et al., 2014), 7 primary schools in Greece (Diapouli et al., 2007), and 2 primary schools in Italy (Buonanno et al., 2013b) reported 1.2to 3.5-fold higher values of UFP. Similarly, studies from other non-European countries such as in California (Mullen et al., 2011), Australia (Morawska et al., 2009), and South Korea (Kim et al., 2011) noted considerably higher levels of UFP than the findings obtained in the current investigation. These differences may be associated with seasonal influences, meteorological conditions, or specific characteristics of the environment where schools are located, such as level of development, urbanization, and traffic (World Health Organization [WHO] 2006). School building and classroom characteristics may also account for some of the differences in UFP number concentrations obtained indoors.

The results of the comparisons between building/classroom characteristics and UFP number concentrations suggested that some of those characteristics may in fact be responsible for a part of the indoor particle concentrations, such as density of occupation, which was found to be positively correlated with classroom UFP concentrations. Further, classrooms with woodbased furniture and laminated blinds presented higher number concentrations of UFP. While UFP are known to originate from combustion processes, including wood combustion (Kleeman et al., 1999), there is no evidence that wood-based furniture may passively produce UFP. Therefore, the significant difference in UFP number concentrations regarding this classroom characteristic may be associated with variations in number of classrooms with and without wood furniture (31 vs. 4, respectively). However, this may not be the case for the type of curtains characteristic, since the sample size of classrooms with textile curtains was similar to the size of those with laminated blinds (18 vs. 17 , respectively). Textile curtains may promote a higher deposition of UFP compared with laminated blinds, thus reducing the number concentrations of UFP in suspension (Afshari et al., 2008). Another possible reason may be associated with area of the windows blocked by textile curtains, which is larger than for laminated blinds; considering that some studies reported that outdoor UFP may penetrate into the indoor environment, contributing to the overall indoor UFP concentration (Zhu et al., 2005), there might be less penetration of UFP from the outdoor environment in classrooms with textile blinds, reflected in lower number concentrations of UFP.

The negatively correlated levels between indoor $\mathrm{CO}_{2}$ and UFP concentrations may indicate that a large part of outdoor UFP penetrated into indoor environment when windows were 
TABLE 3. Ultrafine Particles at Schools: Summarized Information From Previously Published Studies

\begin{tabular}{|c|c|c|c|c|c|c|}
\hline Continent & Country & Reference & Study design & $\begin{array}{l}\text { Mean }^{\mathrm{a}} \\
\left(\mathrm{pt} / \mathrm{cm}^{3}\right)\end{array}$ & $\begin{array}{l}\text { Minimum } \\
\left(\mathrm{pt} / \mathrm{cm}^{3}\right)\end{array}$ & $\begin{array}{l}\text { Maximum } \\
\left(\mathrm{pt} / \mathrm{cm}^{3}\right)\end{array}$ \\
\hline \multirow[t]{5}{*}{ Europe } & Portugal & Current study & & $8.69 \times 10^{3}$ & $1.67 \times 10^{3}$ & $2.56 \times 10^{4}$ \\
\hline & & $\begin{array}{l}\text { Fonseca et al. } \\
\text { (2014) }\end{array}$ & $\begin{array}{l}3 \text { preschools; } 8 \text { classrooms; } \\
1 \text { sampling campaign } \\
\text { (May-June); sample } \\
\text { collection during } 9 \text { h per } \\
\text { day. }\end{array}$ & $0.71-1.13 \times 10^{4}$ & $2.23 \times 10^{3}$ & $1.93 \times 10^{5}$ \\
\hline & Spain & $\begin{array}{l}\text { Reche et al. (2014) } \\
\text { and Rivas et al. } \\
\text { (2014) }\end{array}$ & $\begin{array}{l}39 \text { primary schools; } \\
2 \text { sampling campaigns } \\
\text { (January-June and } \\
\text { September-February); } \\
\text { sample collection during } \\
8 \text { h per day. }\end{array}$ & $1.56 \times 10^{4}$ & $3.58 \times 10^{3}$ & $3.09 \times 10^{4}$ \\
\hline & Greece & $\begin{array}{l}\text { Diapouli et al. } \\
\quad(2007)\end{array}$ & $\begin{array}{l}7 \text { primary schools; } \\
2 \text { sampling campaigns } \\
\text { (November-February and } \\
\text { October-December); } \\
\text { sample collection during } \\
8 \text { h per day. }\end{array}$ & $2.38 \times 10^{4}$ & (n.a.) & $5.26 \times 10^{4}$ \\
\hline & Italy & $\begin{array}{l}\text { Buonanno et al. } \\
\text { (2013b) }\end{array}$ & $\begin{array}{l}2 \text { primary schools and } \\
1 \text { secondary school; } \\
3 \text { sampling campaigns } \\
\text { (January, February, and } \\
\text { December); sample } \\
\text { collection during } 5 \mathrm{~h} \text { or } \\
7 \text { h per day. }\end{array}$ & $1.95-3.49 \times 10^{4}$ & (n.a.) & (n.a.) \\
\hline \multirow[t]{3}{*}{$\begin{array}{l}\text { North } \\
\text { America }\end{array}$} & $\begin{array}{l}\text { California, United } \\
\text { States }\end{array}$ & Mullen et al. (2011) & $\begin{array}{l}1 \text { elementary school; } \\
6 \text { classrooms; } 1 \text { sampling } \\
\text { campaign } \\
\text { (June-December). }\end{array}$ & $1.15 \times 10^{4}$ & $0.21 \times 10^{4}$ & $2.17 \times 10^{4}$ \\
\hline & $\begin{array}{l}\text { Texas, United } \\
\text { States }\end{array}$ & $\begin{array}{l}\text { Zhang and Zhu } \\
\text { (2012) }\end{array}$ & $\begin{array}{l}1 \text { elementary school; } \\
2 \text { classrooms; } 1 \text { sampling } \\
\text { campaign (February). }\end{array}$ & $5.90 \times 10^{3}$ & $0.60 \times 10^{3}$ & $29.3 \times 10^{3}$ \\
\hline & Canada & $\begin{array}{l}\text { Weichenthal et al. } \\
\text { (2008) }\end{array}$ & $\begin{array}{l}1 \text { elementary school and } \\
1 \text { secondary school; } \\
37 \text { classrooms; } 1 \text { sampling } \\
\text { campaign } \\
\text { (January-March); sample } \\
\text { collection during } 7 \text { h per } \\
\text { day. }\end{array}$ & $4.61-5.43 \times 10^{3}$ & $1.03-1.16 \times 10^{3}$ & $1.09-1.14 \times 10^{4}$ \\
\hline Oceania & Australia & $\begin{array}{l}\text { Morawska et al. } \\
\text { (2009) }\end{array}$ & $\begin{array}{l}1 \text { primary school; } \\
3 \text { classrooms; } 2 \text { sampling } \\
\text { campaigns } \\
\text { (January-February and } \\
\text { November-December); } \\
\text { sample collection during } \\
23 \text { h per day. }\end{array}$ & (n.a.) & (n.a.) & $1.40 \times 10^{5}$ \\
\hline Asia & South Korea & Kim et al. (2011) & $\begin{array}{l}12 \text { primary schools; } \\
34 \text { classrooms; } 1 \text { sampling } \\
\text { campaign } \\
\text { (November-December) }\end{array}$ & $1.82 \times 10^{4}$ & $0.37 \times 10^{4}$ & $5.28 \times 10^{4}$ \\
\hline
\end{tabular}

Note. (n.a.), Not available.

${ }^{a}$ Based on measurements in classrooms only.

open (lower $\mathrm{CO}_{2}$ concentrations) and that after closing the windows (higher $\mathrm{CO}_{2}$ concentrations), the contribution of UFP from outdoors to indoors may have decreased. However, more detailed information regarding the position of the windows during the sampling campaigns 
needs to be obtained in future investigations, in order to compare daily profiles of indoor UFP with number of open and/or closed windows.

Considering that the P-Track model used in the current study measured particles smaller than $1 \mu \mathrm{m}$ and that UFP are defined as having a diameter less than $0.1 \mu \mathrm{m}$, larger particles may have contributed to the obtained mean concentrations. Nevertheless, Kumar et al. (2011) noted that, unlike mass concentrations, the majority of particle number concentrations consist of particles under $0.1 \mu \mathrm{m}$, and thus the risk of significant bias in the overall number concentrations of UFP in each classroom associated with the quantity of larger particles at the time of sampling is low.

\section{CONCLUSIONS}

In this study UFP were sampled in 10 Portuguese primary schools, which included 35 classrooms. Overall, indoor number concentrations of UFP obtained in the current study were similar to those of national and some international studies. However, the levels varied considerably $\left(3.8\right.$ to $16 \times 10^{3}$ $\mathrm{pt} / \mathrm{cm}^{3}$ ) among the schools, suggesting that certain parameters, such as building/classroom characteristics, occupant behavior and activities, or outdoor environment, may influence the indoor concentrations of UFP. In addition, the obtained results need to be interpreted with caution since there are no official guidelines for UFP; therefore, it was not possible to establish whether the measured levels posed a health risks for children in these 10 schools. Ultrafine particle concentrations were significantly correlated with $\mathrm{CO}_{2}$ concentrations, thus possibly indicating that outdoor air was a significant contributor to UFP indoors. The intensity and frequency of ventilation may influence the indoor particle number concentrations. However, further information regarding the daily setup of windows during occupation hours is needed in order to fully explore these findings. Schools represent an environment where children spend most of their time. Since IAQ affects respiratory health of school children, prevention of windows opening cannot be a suitable solution to control indoor UFP pollution. Therefore, special attention needs to be given to source control and prevention in order to reduce major emissions of UFP.

\section{SUPPLEMENTAL DATA}

Supplemental data for this article can be accessed at http://dx.doi.org/10.1080/ 15287394.2015.1048866

\section{ORCID}

João Cavaleiro Rufo (1) http://orcid.org/ 0000-0003-1175-242X

\section{FUNDING}

This study was performed in the framework of the ARIA project financed by Fundação para a Ciência e Tecnologia (PTDC/DTP-SPA/1522/ 2012, FCOMP-01-0124-FEDER-028709), the project "E2BE" (NORTE-07-0124-FEDER000036) financed by the Portuguese CCDR-N through the European Union FEDER programme, and the fellowship SFRH/BPD/ $65722 / 2009$.

\section{REFERENCES}

Afshari, A., and C. Reinhold. 2008. Deposition of fine and ultrafine particles on indoor surface materials. Indoor Built Environ. 17: 247-251.

Annesi-Maesano, I., N. Baiz, S. Banerjee, P. Rudnai, S. Rive, and Sinphonie Grp. 2013. Indoor air quality and sources in schools and related health effects. J. Toxicol. Environ. Health B 16: 491-550.

ASHRAE. 2004. Standard 62.1: Ventilation for Acceptable Indoor Air quality. Atlanta, GA: American Society of Heating, Refrigeration, and, Air-Conditioning and Engineers.

Buonanno, G., F. C. Fuoco, L. Morawska, and L. Stabile. 2013b. Airborne particle concentrations at schools measured at different spatial scales. Atmos. Environ. 67: 38-45. 
Buonanno, G., S. Marini, L. Morawska, and F. C. Fuoco. 2012. Individual dose and exposure of Italian children to ultrafine particles. Sci. Total Environ. 438: 271-277.

Buonanno, G., G. B. Marks, and L. Morawska. 2013a. Health effects of daily airborne particle dose in children: Direct association between personal dose and respiratory health effects. Environ. Pollut. 180: 246-250.

Buonanno, G., L. Stabile, and L. Morawska. 2014. Personal exposure to ultrafine particles: The influence of time-activity patterns. Sci. Total Environ. 468: 903-907.

Carosino, C. M., K. J. Bein, L. E. Plummer, A. R. Castaneda, Y. J. Zhao, A. S. Wexler, and K. E. Pinkerton. 2015. Allergic airway inflammation is differentially exacerbated by daytime and nighttime ultrafine and submicron fine ambient particles: Heme oxygenase- 1 as an indicator of PM-mediated allergic inflammation. J. Toxicol. Environ. Health A 78: 254-266.

Correia de Sousa, J., M. L. Silva, F. A. Lobo, and J. Yaphe. 2010. Asthma incidence and accuracy of diagnosis in the Portuguese sentinel practice network. Primary Care Respir. J. 19: 352-357.

Daisey, J. M., W. J. Angell, and M. G. Apte. 2003. Indoor air quality, ventilation and health symptoms in schools: An analysis of existing information. Indoor Air 13: 53-64.

Diapouli, E., A. Chaloulakou, and N. Spyrellis. 2007. Levels of ultrafine particles in different microenvironments-Implications to children exposure. Sci. Total Environ. 388: 128-136.

Englert, N. 2004. Fine particles and human health-A review of epidemiological studies. Toxicol Lett 149: 235-242.

Etzel, R. A. 2007. Indoor and outdoor air pollution: Tobacco smoke, moulds and diseases in infants and children. Int. J. Hyg. Environ. Health 210: 611-616.

Ferreira, A. J., J. Cemlyn-Jones, and C. R. Cordeiro. 2013. Nanoparticles, nanotechnology and pulmonary nanotoxicology. Rev. Portuguesa Pneumol. 19: 28-37.

Fonseca, J., K. Slezakova, S. Morais, and M. C. Pereira. 2014. Assessment of ultrafine particles in Portuguese preschools: Levels and exposure doses. Indoor Air 24: 618-628.

Foos, B., M. Marty, J. Schwartz, W. Bennett, J. Moya, A. M. Jarabek, and A. G. Salmon. 2008. Focusing on children's inhalation dosimetry and health effects for risk assessment: An introduction. J. Toxicol. Environ. Health A 71: 149-165.

Fromme, H., D. Twardella, S. Dietrich, D. Heitmann, R. Schierl, B. Liebl, and H. Ruden. 2007. Particulate matter in the indoor air of classrooms-Exploratory results from Munich and surrounding area. Atmos. Environ. 41: 854-866.

International Standardization Organization. 2004. 16000-1: Indoor air-Part 1: General aspects of sampling strategy. http://www.iso. org/iso/home/store/catalogue_tc/catalogue detail.htm?csnumber $=39844^{-}$

Kim, J. L., L. Elfman, G. Wieslander, M. Ferm, K. Toren, and D. Norback. 2011. Respiratory health among Korean pupils in relation to home, school and outdoor environment. J. Korean Med. Sci. 26: 166-173.

Kleeman, M. J., J. J. Schauer, and G. R. Cass. 1999. Size and composition distribution of fine particulate matter emitted from wood burning, meat charbroiling, and cigarettes. Environ. Sci. Technol. 33: 3516-3523.

Kumar, P., A. Robins, S. Vardoulakis, and P. Quincey. 2011. Technical challenges in tackling regulatory concerns for urban atmospheric nanoparticles. Particuology 9: 566-571.

Levy, J. I., D. H. Bennett, S. J. Melly, and J. D. Spengler. 2003. Influence of traffic patterns on particulate matter and polycyclic aromatic hydrocarbon concentrations in Roxbury, Massachusetts. J. Expos. Anal. Environ. Epidemiol. 13: 364-371.

Madureira, J., M. C. M. Alvim-Ferraz, S. Rodrigues, C. Goncalves, M. C. Azevedo, E. Pinto, and O. Mayan. 2009. Indoor air quality in schools and health symptoms among Portuguese teachers. Hum. Ecol. Risk Assess. 15: 159-169.

Madureira, J., I. Paciencia, and E. D. Fernandes. 2012. Levels and indoor-outdoor relationships of size-specific particulate matter in 
naturally ventilated Portuguese schools. J. Toxicol. Environ. Health A 75: 1423-1436.

Mahyuddin, N., H. Awbi, and M. Alshitawi. 2008. Investigating carbon dioxide in high occupancy buildings with particular application to classrooms. Indoor Air 2008, Copenhagen, Denmark, pp. 17-22.

Mazaheri, M., S. Clifford, R. Jayaratne, M. A. M. Mokhtar, F. Fuoco, G. Buonanno, and L. Morawska. 2014. School children's personal exposure to ultrafine particles in the urban environment. Environ. Sci. Technol. 48: 113-120.

Morawska, L., A. Afshari, G. N. Bae, G. Buonanno, C. Y. H. Chao, O. Hanninen, W. Hofmann, C. Isaxon, E. R. Jayaratne, P. Pasanen, T. Salthammer, M. Waring, and A. Wierzbicka. 2013. Indoor aerosols: From personal exposure to risk assessment. Indoor Air 23: 462-487.

Morawska, L., C. R. He, G. Johnson, H. Guo, E. Uhde, and G. Ayoko. 2009. Ultrafine particles in indoor air of a school: Possible role of secondary organic aerosols. Environ. Sci. Technol. 43: 9103-9109.

Morawska, L., Z. Ristovski, E. R. Jayaratne, D. U. Keogh, and X. Ling. 2008. Ambient nano and ultrafine particles from motor vehicle emissions: Characteristics, ambient processing and implications on human exposure. Atmos. Environ. 42: 8113-8138.

Mullen, N. A., S. Bhangar, S. V. Hering, N. M. Kreisberg, and W. W. Nazaroff. 2011. Ultrafine particle concentrations and exposures in six elementary school classrooms in northern California. Indoor Air 21: 77-87.

Oliveira Fernandes, E., H. Gustafsson, O. Seppänen, D. Crump, and G. Ventura Silva. 2008. WP3 final report on characterization of spaces and sources. EnVIE Project. Brussels, Belgium: European Commission 6th Framework Programme of Research.

Penttinen, P., K. L. Timonen, P. Tiittanen, A. Mirme, J. Ruuskanen, and J. Pekkanen. 2001. Number concentration and size of particles in urban air: Effects on spirometric lung function in adult asthmatic subjects. Environ. Health Perspect. 109: 319-323.
Peters, A., H. E. Wichmann, T. Tuch, J. Heinrich, and J. Heyder. 1997. Respiratory effects are associated with the number of ultrafine particles. Am. J. Respir. Crit. Care 155: 1376-1383.

Reche, C., M. Viana, I. Rivas, L. Bouso, M. Alvarez-Pedrerol, A. Alastuey, J. Sunyer, and X. Querol. 2014. Outdoor and indoor UFP in primary schools across Barcelona. Sci. Total Environ. 493: 943-953.

Rivas, I., M. Viana, T. Moreno, M. Pandolfi, F. Amato, C. Reche, L. Bouso, M. AlvarezPedrerol, A. Alastuey, J. Sunyer, and X. Querol. 2014. Child exposure to indoor and outdoor air pollutants in schools in Barcelona, Spain. Environ. Int. 69: 200-212.

Schwartz, J. 2004. Air pollution and children's health. Pediatrics 113: 1037-1043.

Selgrade, M. K., C. G. Plopper, M. I. Gilmour, R. B. Conolly, and B. S. P. Foos. 2008. Assessing the health effects and risks associated with children's inhalation exposuresAsthma and allergy. J. Toxicol. Environ. Health A 71: 196-207.

Semmler, M., J. Seitz, F. Erbe, P. Mayer, J. Heyder, G. Oberdorster, and W. G. Kreyling. 2004. Long-term clearance kinetics of inhaled ultrafine insoluble iridium particles from the rat lung, including transient translocation into secondary organs. Inhal. Toxicol. 16: 453-459.

Sioutas, C., R. J. Delfino, and M. Singh. 2005. Exposure assessment for atmospheric ultrafine particles (UFPs) and implications in epidemiologic research. Environ. Health Perspect. 113: 947-955.

Slezakova, K., M. D. Alvim-Ferraz, and M. D. Pereira. 2012. Elemental characterization of indoor breathable particles at a Portuguese urban hospital. J. Toxicol. Environ. Health A 75: 909-919.

Stanek, L. W., J. D. Sacks, S. J. Dutton, and J. J. B. Dubois. 2011. Attributing health effects to apportioned components and sources of particulate matter: An evaluation of collective results. Atmos. Environ. 45: 5655-5663.

Terzano, C., F. Di Stefano, V. Conti, E. Graziani, and A. Petroianni. 2010. Air pollution 
ultrafine particles: Toxicity beyond the lung. Eur. Rev. Med. Pharmaco. 14: 809-821.

Vigotti, M. A., F. Chiaverini, P. Biagiola, and G. Rossi. 2007. Urban air pollution and emergency visits for respiratory complaints in Pisa, Italy. J. Toxicol. Environ. Health A 70: 266-269.

Vinzents, P. S., P. Moller, M. Sorensen, L. E. Knudsen, O. Hertel, F. P. Jensen, B. Schibye, and S. Loft. 2005. Personal exposure to ultrafine particles and oxidative DNA damage. Environ. Health Perspect. 113: 1485-1490.

Wallace, L., and C. Howard-Reed. 2002. Continuous monitoring of ultrafine, fine, and coarse particles in a residence for 18 months in 1999-2000. J. Air Waste Manage. Assoc. 52: 828-844.

Weichenthal, S., A. Dufresne, and C. InfanteRivard. 2007. Indoor ultrafine particles and childhood asthma: Exploring a potential public health concern. Indoor Air 17: 81-91.

Weichenthal, S., A. Dufresne, C. InfanteRivard, and L. Joseph. 2008. Characterizing and predicting ultrafine particle counts in Canadian classrooms during the winter months: Model development and evaluation. Environ. Res. 106: 349-360.

World Health Organization, ed. 2006. Air quality guidelines global update 2005: Particulate matter, ozone, nitrogen dioxide and sulfur dioxide. Copenhagen, Denmark: World Health Organization.

Zhang, G., J. Spickett, K. Rumchev, A. H. Lee, and S. Stick. 2006. Indoor environmental quality in a 'low allergen' school and three standard primary schools in Western Australia. Indoor Air 16: 74-80.

Zhang, Q., and Y. Zhu. 2012. Characterizing ultrafine particles and other air pollutants at five schools in south Texas. Indoor Air 22: $33-42$.

Zhu, Y. F., W. C. Hinds, M. Krudysz, T. Kuhn, J. Froines, and C. Sioutas. 2005. Penetration of freeway ultrafine particles into indoor environments. J. Aerosol Sci. 36: 303-322. 